\title{
Peningkatan Hasil Belajar Bahasa Indonesia Kajian Teks Deskripsi melalui Model Jigsaw Siswa SMP
}

\author{
Anik Masruroh ${ }^{(1)}$ \\ ${ }^{1}$ Guru SMP Negeri 2 Watulimo \\ Email: ${ }^{1}$ anikmasruroh1708@yahoo.com, \\ DOI: https://doi.org/10.28926/riset_konseptual.v2i3.67
}

\begin{abstract}
ABSTRAK
Rendahnya hasil belajar bahasa Indonesia salah satu penyebabnya adalah pembelajaran Bahasa Indonesia cenderung kepada pembelajaran bersifat konvensional yaitu hanya menggunakan metode ceramah, sedangkan pada hakekatnya pembelajaran Bahasa Indonesia menuntut siswa dapat berpartisipasi aktif dalam pembelajaran, siswa dapat mencari dan menemukan masalahnya sendiri (KTSP menuju ke Kurikulum 2013). Tujuan penelitian ini untuk mendapatkan jawaban objektif tentang peningkatan hasil belajar bahasa Indonesia materi struktur dan unsur kebahasaan dari teks deskripsi tentang objek melalui model jigsaw pada siswa kelas VII A semester 1 tahun pelajaran 2017/2018 di SMP Negeri 2 Watulimo. Siklus penelitian meliputi planning (rencana), action (tindakan), observation (pengamatan), dan refleksi (refleksi). Hasil penelitian menunjukkan bahwa hasil tes siklus I jumlah nilai yang diperoleh 1820 , rata-rata 70 dengan persentase ketuntasan $76,92 \%$ sedangkan pada penelitian siklus II jumlah nilai yang diperoleh 2020, rata-rata 77,69 dengan ketuntasan $96,15 \%$. Peningkatan ketuntasan hasil belajar terlihat pada siklus I dengan rata-rata nilai 70 , rata-rata nilai siklus II 77,69 sehingga meningkat sebesar 7,69. Ketuntasan siklus I sebesar 76,92\%, siklus II sebesar $96,15 \%$, sehingga meningkat sebesar $19,23 \%$. Dari hasil analisis dapat disimpulkan bahwa model jigsaw dapat meningkatkan hasil belajar Bahasa Indonesia materi struktur dan unsur kebahasaan dari teks deskripsi tentang objek pada siswa kelas VII A semester 1 tahun pelajaran 2017/2018 di SMP Negeri 2 Watulimo.
\end{abstract}

Kata kunci: teks deskripsi, bahasa indonesia, jigsaw,

\section{PENDAHULUAN}

Kegiatan belajar mengajar sehari-hari yang dilakukan guru terbiasa dengan menggunakan metode ceramah dan latihan-latihan soal secara individual, sehingga tidak ada interaksi antarsiswa. Metode yang dilakukan guru tersebut belum bisa menunjukkan hasil belajar yang maksimal sesuai target. Padahal berhasil atau tidaknya tujuan pencapaian pengajaran di sekolah banyak tergantung pada kegiatan belajar mengajar yang dilaksanakan guru di dalam kelas. Guru masih kurang didalam membangkitkan motivasi belajar siswa. Siswa cenderung pasif dan tidak berani bertanya mengenai materi yang yang belum dimengerti, sehingga evaluasi belajar siswa mendapatkan nilai yang kurang memuaskan. Bagaimana guru menerapkan pembelajaran dan strategi belajarnya akan mempengaruhi hasil belajar siswa.

Belajar, Oemar Hamalik (2014:27), suatu proses perubahan tingkah laku individu melalui interaksi dengan lingkungan. Slameto (2012:2) berpendapat bahwa belajar ialah suatu proses usaha yang dilakukan seseorang untuk memperoleh suatu perubahan tingkah laku secara keseluruhan, sebagai hasil pengalamannya sendiri dalam interaksi dengan lingkungannya. Hal ini sesuai dengan pendapat Suparwoto (2014:41) bahwa belajar pada intinya adalah proses internalisasi dalam diri individu yang belajar dapat dikenali produk belajarnya yaitu berupa perubahan, baik penguasaan materi, tingkah laku, maupun keterampilan.

William Burton, belajar adalah suatu proses perubahan tingkah laku individu melalui interaksi dengan lingkungan. Di dalam interaksi inilah terjadi serangkaian pengalaman - pengalaman belajar, Suparwoto (2014:41). Menurut Winkel (2015:68) belajar adalah semua aktivitas mental atau psikis yang berlangsung dalam interaksi aktif dalam lingkungan, yang menghasilkan perubahan- perubahan dalam pengelolaan 
pemahaman. Sedangkan Hilgard (Purwanto, 2012:51) belajar merupakan proses perbuatan yang dilakukan dengan sengaja, yang kemudian menimbulkan perubahan, yang keadaannya berbeda dari perubahan yang ditimbulkan oleh lainnya. Sifat perubahannya relatif permanen, tidak akan kembali kepada keadaan semula. Tidak bisa diterapkan pada perubahan akibat situasi sesaat, seperti perubahan akibat kelelahan, sakit, mabuk, dan sebagainya. Dan belajar menurut Gagne (Mulyani Sumantri \& Johar Permana, 2012:16) belajar merupakan sejenis perubahan yang diperlihatkan dalam perubahan tingkah laku, yang keadaaannya berbeda dari sebelum individu berada dalam situasi belajar dan sesudah melakukan tindakan yang serupa itu. Perubahan terjadi akibat adanya suatu pengalaman atau latihan. Berbeda dengan perubahan serta-merta akibat refleks atau perilaku yang bersifat naluriah.

Surya mendefinisikan belajar adalah suatu proses usaha yang dilakukan individu untuk memperoleh suatu perubahan tingkah laku yang baru keseluruhan, sebagai hasil pengalaman individu itu sendiri dalam interaksinya dengan lingkungan, Sudjana (2014:22). Menurut Oemar Hamalik (2014:280) mengungkapkan empat prinsip belajar yaitu belajar senantiasa harus bertujuan, terarah, dan jelas bagi siswa, karena tujuan akan menuntut dalam belajar, jenis belajar yang paling utama adalah untuk berpikir kritis, belajar memerlukan pemahaman atas hal - hal yang dipelajari sehingga memperoleh pengertian-pengertian, dan keinginan dan kemauan yang kuat untuk mencapai tujuan dan hasil.

Dari pendapat para ahli disimpulkan bahwa di dalam belajar terdapat perubahan tingkah laku dalam diri seseorang berupa pengetahuan, pemahaman, maupun sikap yang diperoleh melalui proses belajar, yang merupakan hasil interaksi dengan lingkungan sebagai proses pembelajaran. Dapat dikatakan dengan belajar seseorang dapat memperoleh sesuatu yang baru baik itu pengetahuan, keterampilan maupun sikap.

Sudjana (2014:20) memberikan deskripsi bahwa hakikat hasil belajar sebagai perubahan tingkah laku individu yang mencakup aspek kognitif, afektif, dan psikomotorik. Selanjutnya Sudjana (2014:38) menjelaskan hasil belajar yang dicapai siswa dipengaruhi dua faktor utama yakni faktor dari dalam diri dan luar diri siswa atau faktor lingkungan.

Rumusan tujuan pendidikan dalam sisdiknas, baik tujuan kurikuler maupun tujuan instruksional, menggunakan hasil belajar dari Bloom (Purwanto, 2012:50) yang secara garis besar membaginya dalam tiga ranah yaitu (1) ranah kognitif, perubahan perilaku yang terjadi dalam kawasan kognisi. Proses belajar yang melibatkan kawasan kognisi meliputi kegiatan sejak dari penerimaan stimulus, penyimpanan dan pengolahan dalam otak menjadi informasi hingga pemanggilan kembali informasi ketika diperlukan untuk menyelesaikan masalah. Menurut Bloom secara hirarki tingkat hasil belajar kognitif mulai dari yang paling rendah dan sederhana yaitu hafalan sampai yang paling tinggi dan kompleks yaitu evaluasi. Enam tingkatan itu adalah pengetahuan (C1), pemahaman (C2), penerapan (C3), analisis (C4), sintesis (C5) dan evaluasi (C6), (2) ranah afektif, Kratwohl membagi belajar afektif menjadi lima tingkat, yaitu penerimaan (merespon rangsangan), partisipasi, penilaian (menentukan pilihan sebuah nilai dari rangsangan), organisasi (menghubungkan nilai - nilai yang dipelajari), dan internalisasi (menjadikan nilai-nilai sebagai pedoman hidup). Hasil belajar disusun secara hirarkis mulai dari tingkat yang paling rendah hingga yang paling tinggi. Jadi ranah afektif adalah yang berhubungan dengan nilai-nilai yang kemudian dihubungkan dengan sikap dan perilaku (Purwanto, 2012:51), (3) dan ranah psikomotor, Simpson mengklasifikasikan hasil belajar psikomotorik menjadi enam yaitu,persepsi (membedakan gejala), kesiapan (menempatkan diri untuk memulai suatu gerakan), gerakan terbimbing (meniru model yang dicontohkan), gerakan terbiasa (melakukan gerakan tanpa model hingga mencpai kebiasaan), gerakan kompleks (melakukan serang serangkaian gerakan secara berurutan), dan kreativitas (menciptakan gerakan dan kombinasi gerakan baru yang orisinil atau asli) (Purwanto, 2012:51). Disimpulkan 
hasil belajar merupakan perubahan tingkah laku individu yang mencakup tiga aspek yaitu kognitif, afektif, dan psikomotorik.

Faktor yang mempengaruhi hasil belajar, Dalyono (2013:55) mengemukakan (1) faktor internal, meliputi kesehatan, intelegensi, bakat, minat, motivasi, cara belajar dan (2) faktor eksternal, meliputi keluarga, sekolah, masyarakat dan lingkungan sekitar.

Pembelajaran kooperatif model Jigsaw ini mengambil pola cara bekerja sebuah gergaji (zigzag), yaitu siswa melakukan suatu kegiatan belajar dengan cara bekerja sama dengan siswa lain untuk mencapai tujuan bersama. Sebuah model belajar yang menitik beratkan pada kerja kelompok siswa dalam bentuk kelompok kecil. Siswa belajar dalam kelompok kecil yang terdiri dari empat sampai enam orang secara heterogen dan siswa bekerja sama saling ketergan-tungan positif dan bertanggung jawab secara mandiri atas ketuntasan bagian materi pelajaran yang harus dipelajari dan menyampaikan materi tersebut kepada anggota kelompok yang lain (Kuntjojo, 2015:14). Model pembelajaran ini siswa bekerja sama dengan sesama siswa dalam suasana gotong royong dan mempunyai banyak kesempatan untuk mengolah informasi dan meningkatkan keterampilan berkomunikasi (Hasan, 2015:33)

Model ini didesain untuk meningkatkan rasa tanggung jawab siswa terhadap pembelajarannya sendiri dan juga pembelajaran orang lain. Siswa tidak hanya mempelajari materi yang diberikan, tetapi juga harus siap memberikan dan mengajarkan materi tersebut pada anggota kelompoknya yang lain. Zaini menegaskan bahwa materi yang akan dipelajari dapat dapat dibagi menjadi beberapa bagian dan materi tersebut tidak mengharuskan urutan penyampaian (Zaini, 2014: 56).

Langkah-langkah model pembelajaran kooperatif tipe jigsaw Priyanto menjelaskan yaitu (1) pembentukan kelompok asal, (2) pembelajaran pada kelompok asal, (3) pembentukan kelompok ahli, (4) diskusi kelompok ahli, (5) diskusi kelompok asal, (6) diskusi kelas, (7) pemberian kuis ( Made Wena, 2011: 194-195). Kelebihan model jigsaw terletak pada interaksi yang terjadi dalam belajar yang dapat memacu terbentuknya ide baru dan memperkaya perkembangan intelektual siswa, seperti meningkatkan kerja sama untuk mempelajari materi yang ditugaskan, meningkatkan rasa tanggung jawab siswa terhadap pembelajarannya sendiri dan juga pembelajaran orang lain, melatih siswa untuk lebih aktif dalam berbicara dan berpendapat, dan pemerataan penguasaan materi dapat dicapai dalam waktu yang lebih singkat.

\section{METODE}

Penelitian tindakan kelas menerapkan model pembelajaran jigsaw untuk meningkatkan profesionalitas guru sebagai agen dan fasilitator pembelajaran melalui perubahan pelaksanaan proses belajar mengajar menjadi proses pembelajaran. Penelitian Tindakan Kelas merupakan suatu bentuk penelitian yang bersifat reflektif dengan melakukan tindakan-tindakan tertentu agar dapat memperbaiki atau meningkatkan praktek pembelajaran di kelas secara proposional. Penelitian tindakan kelas ini dilaksanakan dalam empat tahap, yaitu (1) tahap perencanaan (2) tahap pelaksanaan (3) tahap pengamatan, dan (4) tahap refleksi. Subjek penelitian siswa kelas VII A semester 1 tahun pelajaran 2017/2018, dengan jumlah siswa 26 terdiri dari terdiri dari 13 siswa laki-laki dan 13 siswa perempuan.

\section{Rancangan Penelitian}

Penelitian dilakukan dengan Penelitian Tindakan Kelas (PTK), bentuk penelitian reflektif yang dilakukan oleh guru sendiri yang hasilnya dapat dimanfaatkan sebagai alat untuk pengembangan kurikulum, pengembangan sekolah, pengembangan keahlian mengajar, dan sebagainya. Sesuai dengan jenis penelitian yang dipilih, yaitu penelitian tindakan, maka penelitian ini menggunakan model penelitian tindakan dari Kemmis dan Taggart (Arikunto, 2014:83), yaitu berbentuk spiral dari siklus yang satu ke siklus yang berikutnya. Setiap siklus meliputi planning (rencana), action (tindakan), observation (pengamatan), dan refleksi (refleksi). 


\section{Perencanaan}

Beberapa aktifitas dari tahap perencanaan yakni mengidentifikasi masalah yang terjadi dalam pembelajaran, menyusun silabus, menyusun skenario pembelajaran, menyusun rpp, menyusun lembar kerja, menyusun instrumen tes, menyusun kelompok siswa, dan pelaksanaan.

\section{Pelaksanaan Tindakan}

Tahap pelaksanaan tindakan dilakukan dengan menerapkan model pembelajaran jigsaw. Proses pembelajaran dilaksanakan mengacun pada Rencana Pelaksanaan Pembelajaran (RPP).

\section{Pengamatan}

Pada tahap ini, kolaborator mengamati aktivitas siswa selama kegiatan belajar mengajar. Semua peristiwa yang ditemui dicatat kemudian dilaporkan kepada peneliti. Hasil yang diperoleh dalam penelitian sebagai bahan pertimbangan perencanaan pembelajaran berikutnya.

\section{Refleksi}

Refleksi dilakukan setelah pembelajaran selesai. Semua temuan ditulis oleh kolaborator dengan teliti. Data yang terekam pada dievaluasi dan diambil kesimpulan untuk membuat rencana pelaksanaan pembelajaran selanjutnya.. Apabila dalam penelitian masih terdapat indikator yang belum tercapai maka pembelajaran akan ditinjau kembali dan akan dilanjutkan pada penelitian selanjutnya.

\section{Teknik Pengumpulan Data}

Data-data yang diperoleh dari penelitian ini merupakan data hasil tes. Teknik tes dalam penelitian ini digunakan untuk menggali data hasil belajar siswa kelas VII $A$ pada materi struktur dan unsur kebahasaan dari teks deskripsi tentang objek melalui model jigsaw.

\section{Teknik Analisis Data}

Adapun analisis data yang digunakan pada penelitian ini adalah metode kuantitatif. Metode ini digunakan untuk menganalisis data tes belajar siswa dalam pembelajaran, yang dilakukan dengan cara memberikan evaluasi berupa soal tes pada setiap akhir siklus. Analisis ini dihitung dengan menggunakan statistik sederhana yaitu (1) menentukan nilai rata-rata. Peneliti melakukan penjumlahan nilai yang diperoleh siswa, yang selanjutnya dibagi dengan jumlah siswa yang ada di kelas tersebut sehingga diperoleh rata-rata tes, (2) ketuntasan belajar, ada dua kategori ketuntasan belajar yaitu secara perorangan dan secara klasikal. Berdasarkan petunjuk pelaksanaan belajar mengajar yaitu seorang siswa telah tuntas belajar bila telah mencapai skor $75 \%$ atau nilai 75 , dan kelas disebut tuntas belajar bila di kelas tersebut terdapat $85 \%$ yang telah mencapai daya serap lebih dari atau sama dengan $75 \%$.

HASIL

Paparan prasiklus pembelajaran yang dilakukan guru di kelas VII A pada pembelajaran KD 3.2 Menelaah struktur dan unsur kebahasaan dari teks deskripsi tentang objek (sekolah, tempat wisata, tempat bersejarah, dan atau suasana pentas seni daerah) yang didengar dan dibaca, pada indikator menentukan dan memperbaiki kesalahan penggunaan kata, kalimat, ejaan dan tanda baca pada hari Senin tanggal 4 September 2017 jam ke 6-7-8 mengalami banyak kesulitan, terlihat dari tingkat pemahaman siswa masih kurang. Hal ini terlihat dari hasil ulangan post tes yang dilakukan guru diakhir pembelajaran, nilai siswa secara klasikal memperoleh nilai ratarata sebesar 52,34 dari 26 jumlah siswa kelas VII A. Jumlah siswa yang tuntas 8 siswa atau $30,78 \%$, sedangkan siswa yang tidak tuntas 18 siswa atau $69,23 \%$. Rata-rata nilai 
yang diperoleh siswa kelas VII A tersebut masih jauh dari KKM K13 yang ditentukan yaitu 61.

Paparan siklus I yang dilaksanakan 2 kali pertemuan yaitu siklus I pertemuan 1 dilaksanakan pada hari Senin tanggal 11 September 2017 jam ke 6-7-8 dan siklus I pertemuan 2 dilaksanakan pada hari Senin tanggal 18 September 2017 jam ke 6-7-8. Menunjukkan bahwa siswa memperoleh nilai pada rentang 90-100 sebanyak 1 siswa atau $3,84 \%$ dengan jumlah nilai 90 masuk kategori tuntas, siswa yang memperoleh nilai pada rentang 80-89 sebanyak 7 siswa atau 26,92\% dengan jumlah nilai 560 masuk kategori tuntas, siswa yang memperoleh nilai pada rentang 70-79 sebanyak 12 siswa atau 46,15\% dengan jumlah nilai 840 masuk kategori tuntas, siswa yang memperoleh nilai pada rentang 1-60 sebanyak 6 siswa atau 23,07\% dengan jumlah nilai 330 masuk kategori tidak tuntas. Jumlah nilai yang diperoleh 1820 , rata-rata 70 dengan ketuntasan 76,92\%. Hasil paparan siklus II yangdilaksanakan 2 kali pertemuan yaitu siklus II pertemuan 1 dilaksanakan pada hari Senin tanggal 25 September 2017, jam ke 6-7-8 dan siklus II pertemuan 2 dilaksanakan pada hari Senin tanggal 2 Oktober 2017 jam ke 6-7-8. Hasil menunjukkan bahwa siswa yang memperoleh nilai pada rentang 90 - 100 sebanyak 4 siswa atau 15,38\% dengan jumlah nilai 360 masuk kategori tuntas, siswa yang memperoleh nilai pada rentang 80-89 sebanyak 13 siswa atau $50 \%$ dengan jumlah nilai 1040 masuk kategori tuntas, siswa yang memperoleh nilai pada rentang 70-79 sebanyak 8 siswa atau 30,76\% dengan jumlah nilai 560 masuk kategori tuntas, siswa yang memperoleh nilai pada rentang 1-60 sebanyak 1 siswa atau 3,84\% dengan jumlah nilai 60 masuk kategori tidak tuntas. Jumlah nilai yang diperoleh 2020, rata-rata 77,69 dengan ketuntasan $96,15 \%$. Hasil refleksi pada siklus II ini siswa sudah tampak serius mengikuti pembelajaran, tidak ada lagi siswa yang berguarau dengan temannya, dan guru dalam memberikan pembelajaran sudah terinci pada indikator pembelajaran.

\section{PEMBAHASAN}

Paparan perbandingan hasil pelaksanaan siklus I dan siklus II menunjukkan hasil belajar siswa kelas VII A semester 1 tahun pelajaran 2017/2018 SMP Negeri 2 Watulimo pada materi struktur dan unsur kebahasaan dari teks deskripsi tentang objek. Hasil yang diperoleh siswa pada siklus II telah memenuhi indikator keberhasilan penelitian sehingga pelaksanaan penelitian tindakan kelas dihentikan sampai pada siklus II. Hasil penelitian siklus I dan siklus II pada penelitian siklus I jumlah nilai yang diperoleh 1820, rata-rata 70 dengan ketuntasan $76,92 \%$ sedangkan pada penelitian siklus II jumlah nilai yang diperoleh 2020 , rata-rata 77,69 dengan ketuntasan $96,15 \%$. Dengan demikian hasil penelitian siklus I dan siklus II menunjukkan bahwa rata-rata hasil belajar siklus I sebesar 70 dan siklus II sebesar 77,69. Ketuntasan belajar siklus I sebesar 76,92\% sedangkan siklus II sebesar 96,15\%. Hasil belajar siklus I dengan rata-rata nilai 70 , rata-rata nilai siklus $\| 77,69$ sehingga meningkat sebesar 7,69. Ketuntasan siklus I sebesar 76,92\%, siklus II sebesar $96,15 \%$, sehingga meningkat sebesar 19,23\%. Dari hasil analisis data di atas dapat disimpulkan bahwa model jigsaw dapat meningkatkan hasil belajar Bahasa Indonesia materi struktur dan unsur kebahasaan dari teks deskripsi tentang objek pada siswa kelas VII A semester 1 tahun pelajaran 2017/2018 di SMP Negeri 2 Watulimo.

\section{KESIMPULAN}

Hasil analisis data menunjukkan bahwa hasil tes siklus I jumlah nilai yang diperoleh 1820 , rata-rata 70 dengan persentase ketuntasan $76,92 \%$ sedangkan pada penelitian siklus II jumlah nilai yang diperoleh 2020, rata-rata 77,69 dengan ketuntasan $96,15 \%$. Hasil siklus I maupun hasil siklus II dapat dibandingkan, bahwa hasil siklus II lebih baik dari hasil siklus I. Sehingga dapat dikatakan bahwa hasil siklus II mengalami peningkatan dibanding hasil siklus I. Peningkatan ketuntasan hasil belajar siswa tersebut dapat adalah hasil tes pada siklus I dengan rata-rata nilai 70 , rata-rata nilai siklus II 77,69 sehingga meningkat sebesar 7,69. Ketuntasan siklus I sebesar 
$76,92 \%$, siklus II sebesar $96,15 \%$, sehingga meningkat sebesar $19,23 \%$. Dari hasil analisis data diatas dapat disimpulkan bahwa model jigsaw dapat meningkatkan hasil belajar Bahasa Indonesia materi struktur dan unsur kebahasaan dari teks deskripsi tentang objek pada siswa kelas VII A semester 1 tahun pelajaran 2017/2018 di SMP Negeri 2 Watulimo.

\section{SARAN}

Saran bagi siswa diharapkan dapat meningkatkan rasa tanggung jawab dan kerjasama secara kooperatif akibat proses belajar dalam kelompok yang dilakukan dengan cara bertemu muka dan berdiskusi antar anggota kelompok. Hasil penelitian diharapkan dapat meningkatkan hasil belajar materi struktur dan unsur kebahasaan dari teks deskripsi tentang objek pada siswa kelas VII A semester 1 tahun pelajaran 2017/2018 di SMP Negeri 2 Watulimo. Bagi guru agar dapat menerapkan model jigsaw untuk pokok bahasan yang lain di SMP Negeri 2 Watulimo. Bagi sekolah hasil penelitian diharapkan dapat memberikan sumbangan yang baik pada pihak SMP Negeri 2 Watulimo untuk memperbaiki pembelajaran.

\section{DAFTAR RUJUKAN}

Arikunto, Suharisimi, 2014. Prosedur Penelitian Suatu Pendekatan Praktik. Jakarta: Rineka Cipta.

Dalyono. M. 2013. Psikologi Pendidikan. Jakarta: Rineka Cipta.

Hamalik, Oemar. 2014. Proses Belajar Mengajar. Jakarta : PT.Bumi Aksara

Hasan, Muhammad Tholchah. 2015. Metode Penelitian Kualitatif. Malang: Lembaga Penelitian Universitas Islam Malang

Kuntjojo. 2015. Metode Penelitian. Kediri: Universitas Nusantara PGRI.

Mulyani Sumantri dan Johar Permana, 2012, Strategi Belajar Mengajar. Jakarta : Direktorat Jendral Pendidikan Tinggi.

Purwanto. 2012. Evaluasi Hasil Belajar.Yogyakarta: Pustaka Pelajar.

Rusman. 2012. Model-Model Pembelajaran. Jakarta: Raja Grafindo Persada.

Slameto. 2012. Belajar dan Faktor-Faktor yang Mempengaruhinya. Jakarta : Rineka Cipta

Sudjana, Nana. 2014. Dasar-Dasar Proses Belajar Mengajar. Jakarta : Bumi Aksara

Sudrajat, Akhmad. 2012. Pengertian Pendekatan, Strategi, Metode, Teknik dan. Model Pembelajaran. Bandung: Sinar Baru Algensindo.

Suparwoto. 2014. Penilaian Proses dan Hasil Pembelajaran Fisika. Yogyakarta: Jurdik Fisika FMIPA UNY

Trianto. 2013. Model-model Pembelajaran Inovatif Berbasis Konstruktivistik. Jakarta: Prestasi .

Wena, Made. 2011. Strategi Pembelajaran Inovatif Kontemporer: Suatu. Tinjauan. Konseptual Operasional. Jakarta: PT. Bumi Aksara

Winkel, W.S. 2015. Psikologi Pengajaran. Jakarta: PT. Gramedia Widia Sarana Indonesia.

Zaini, Hisyam 2014. Strategi Pembelajaran Aktif. Yogyakarta: Insan Mandiri. 